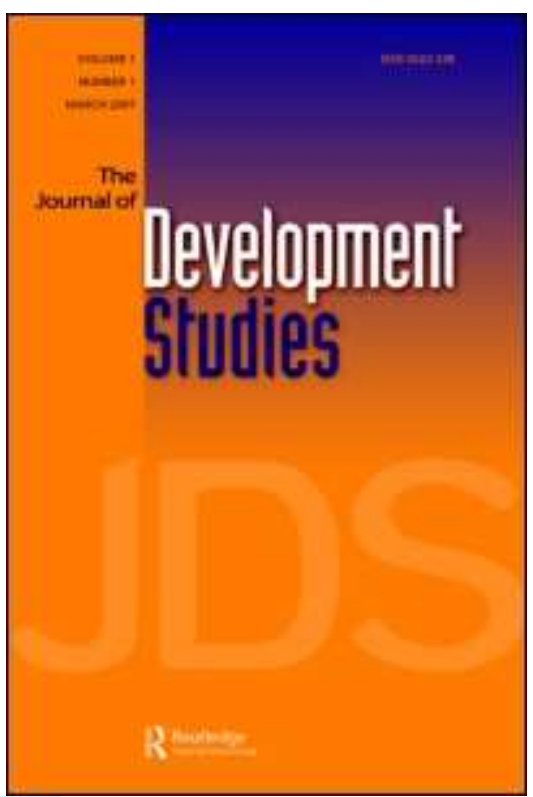

\title{
Understanding Long-Run African Growth: Colonial Institutions or Colonial Education?
}

\begin{tabular}{|r|l|}
\hline Journal: & Journal of Development Studies \\
\hline Manuscript ID: & FJDS-2008-Mar-0007.R1 \\
\hline Manuscript Type: & Original Manuscripts \\
\hline Keywords: & $\begin{array}{l}\text { Economic development < Economics, Education < Education, Sub- } \\
\text { Saharan Africa < Geographical Area }\end{array}$ \\
\hline \multicolumn{2}{|c}{} \\
\hline
\end{tabular}

\section{s scholarONE" \\ Manuscript Central}




\title{
Understanding Long-Run African Growth:
}

\section{Colonial Institutions or Colonial Education?}

\begin{abstract}
Long-term growth in developing countries has been explained in four frameworks: 'extractive colonial institutions' (Acemoglu et al., 2001), 'colonial legal origin' (La Porta et al., 2004) 'geography' (Gallup et al., 1998) and 'colonial human capital' (Glaeser et al., 2004). In this paper we test the 'colonial human capital' explanation for sub-Saharan Africa, controlling for legal origins and geography. Utilizing data on colonial-era education, we find that instrumented human capital explains long-term growth better, and shows greater stability over time, than instrumented measures for extractive institutions. We suggest that the impact of the disease environment on African long-term growth runs through a human capital channel rather than an extractiveinstitutions channel. The effect of education is robust to including variables capturing legal origin and geography, which have additional explanatory power.

JEL codes: O11, P16, P51
\end{abstract}




\section{Introduction}

This paper is an empirical examination of the colonial origins of Africa's economic growth. Developments in growth theory suggest that explanations should be located in the broad areas of geography, institutions and human capital. Whereas the geography school examines factors where one-way causality with growth is beyond reasonable doubt, - including location, precipitation, sunshine and natural endowments - empirical studies on institutions need to address an endogeneity problem. Recent studies have done so by employing variables that precede modern economic growth in the developing world, including the legal systems used by colonising powers (La Porta et al., 2004) and settler mortality (Acemoglu et al., 2001).

This paper extends this approach to the study of human capital's impact on longrun growth in sub-Saharan Africa (hereafter 'Africa'). We focus on Africa because of the availability of colonial data relating to our research topic. Also, Africa's experience occupies a sufficiently distinct place in the development literature to merit separate study of the continent (as testified to by the notorious 'Africa dummy' appearing in much cross-country econometric work). We utilise freshly collected data on African colonial human capital and instrument it with settler mortality. Our main positive finding is that instrumented colonial-era education is a causal factor for long-term growth. This finding is robust to inclusion of additional effects of legal origin and geography. Our education measure explains growth better and shows greater stability over time than do measures for extractive institutions used by Acemoglu et al. (2001). We also find some evidence that institutions are endogenous to education, as suggested by Glaeser et al. (2004). 
1

2

3

4

5

6

7

8

9

10

11

12

13

14

15

16

17

18

19

20

21

22

23

24

25

26

27

28

29

30

31

32

33

34

35

36

37

38

39

40

41

42

43

44

45

46

47

48

49

50

51

52

53

54

55

56

57

58

59

60

The next section reviews the four main schools of thought in the current debate on the roots of long-term growth, followed by a historical background on colonial education in section 3. Section 4 introduces our data and presents the analysis and results. Section 5 concludes with a summary and discussion of our findings. 


\section{Explanations of Long-Term Growth}

\subsection{Extractive Institutions}

Institutions are broadly defined as the written and informal rules, beliefs, norms and habits that 'constrain and liberate human action' (North, 1990). Any empirical study on institutions and growth must come to terms with the pervasive and often elusive nature of institutions - particularly, their manifold manifestations, and the endogeneity of institutions to growth. A milestone study is by Acemoglu et al. (2001) who address both problems by studying a large number of former European colonies and defining their colonial-era institutions generically as 'extractive' or 'constructive'. The authors suggest that where the disease environment was favourable to European settlers, they settled in larger numbers and built societies with economic institutions akin to those in Europe. These would typically include many checks and balances on state power, fostering private entrepreneurship, trade and innovation. In contrast, where the disease environment was not favourable - as indicated by high settler mortality - Europeans created 'extractive institutions': legal constructs endowing the state with large powers and few constraints, designed to effectively transfer natural resources to the colonisers while stifling private initiative and commercial development (Acemoglu et al., 2001: 1375). The authors presume these institutional frameworks (if not concrete institutions) to be persistent, so that settler mortality would be a robust proxy for the quality of both early and current institutions.

One gap in the Acemoglu et al. (2001) analysis is that the two steps in the argument (high European population mortality led to low European population densities, which led to extractive institutions) are not separately tested. Also, they do not examine 
whether their result was driven mainly by the gap in economic performance between settler economies such as the US, Australia and New Zealand and colonies in Africa and Asia. This begs the question if extractive institutions explain performance also within a solely African context We return to both these issues in the empirical section 3 .

\subsection{Legal Origins}

Djankov et al. (2002), Glaeser and Shleifer (2002) and La Porta et al. (1998) address the endogeneity problem besetting institutions by creating a measure of early, colonial-era institutions, which preceded developing-country current growth performance. Their measurement distinguishes between colonial institutions originating from different national legal systems. Again, the presumption is that once introduced, these systems do not change fundamentally and hence legal origin determines the qualities of also current institutions (Glaeser and Shleifer 2002). in our context the differences between Africa's most active colonisers would be relevant. Under French civil law, 'professional judges, legal codes, and written records' are typical while British common law is characterised by 'lay judges, broader legal principle and oral argument' (Glaeser and Shleifer 2002:1193). Joireman (2006) questions this assumption and argues that there is significant heterogeneity within common-law countries. This also applies to colonies: she shows how Kenya and India - which both had common law systems imposed by the British coloniser - have very different colonial and post-colonial legal experiences. But in Djankov et al. (2002), Glaeser and Shleifer (2002) and La Porta et al. (1998), legal-origin differences are successfully linked to measures for present-day institutions including market regulation, property rights, quality of government, political freedom and financial 
development. These concrete institutions, in turn, are shown to systematically relate to growth.

\subsection{Geography}

Yet another group of scholars links differences in economic development patterns to geographical factors. An important analytical advantage is the absence of serious endogeneity problems: geographical factors plausibly have some impact on economic growth, while growth has no or very little direct effect on geography. The four broad areas often cited relate to natural endowments, productivity, diseases, and transport costs (Sachs and Warner, 1997; Gallup et al. 1998; Bloom and Sachs, 1998; Diamond, 1999; Sachs, 2001).

Endowments of 'point resources' (principally oil, gas, diamonds, and precious metals) provide a growth potential which may be successfully exploited to raise income sustainably; but they are also notorious for leading to a 'resource curse' of political and economic instability related to rents. In contrast, endowments with non-point, widespread natural resources such as sunshine, rainfall and soil fertility have historically constituted the most common geographical basis for broad-based and sustainable growth. This may account partly for Africa's growth problems, as its location in the tropics implies that production conditions, particularly in agriculture, are less favourable and more variable than in temperate zones, due to fragile soils and little or infrequent rainfall. A third geographical factor is the incidence of plagues and pests which affect plants and animals (and thereby agricultural productivity) as well as the productivity of human labour. Such diseases (particularly, malaria) are unusually widespread in Africa and their impact is therefore more harmful than in most other parts of the world. Fourth, lack of access to 
seaports or navigable rivers increases local transport costs; a third of all African countries are landlocked, comprising a quarter of its population (Sachs and Warner 1997, Gallup et al. 1998). Also, large distances to world markets increase the transport costs of trade.

Over time, powerful feedback mechanisms may reinforce these barriers to economic development. Low agricultural productivity inhibits an 'agricultural transformation', which historically has been the basis for industrialisation, economic diversification and rising income levels in all now-developed countries (Timmer, 2002). Harsh living conditions lead to thinly settled countries and low incomes, which then constitute an endogenous drag on further growth, for example through demand limitations and larger costs (and lower returns) in infrastructure construction. Small domestic markets also inhibit scale-sensitive technological innovation, widening the 'ecological divide' with developed countries that hinders the adoption of innovations through technology diffusion (Sachs, 2001:22).

\subsection{Human Capital}

The human capital angle on growth in former colonies has recently been argued by Glaeser et al. (2004) and Djankov et al. (2003), based on early work by Schultz (1961), Lipset (1959, 1960), Dewey (1916) and others. As it is the focus of this paper, we discuss it in some detail.

The term human capital was defined by its originator Theodore Schultz (1961:1) as 'skills and knowledge' which are 'a form of capital' and are 'in substantial part a product of deliberate investment'. He also posited the link with economic growth, observing that increases in economic output have been large in comparison with increases in land, man-hours and physical reproducible capital. Investment in human 
capital is probably the major explanation for this difference' (1961:1). Education can be viewed as one such investment in human capital, another one being, for example, health care (Schultz, 1999:67). Our focus is on the education component of human capital.

The key observation in the human capital angle on the colonial roots of Africa's growth, then, is not that settlers took 'institutional fundaments' with them. They took themselves, their human capital, and the means to proliferate the education component of that human capital through their educational systems. As in the Acemoglu et al (2001) account, there is a link with the density of settlement by colonisers, but it does not run via extractive institutions. Instead, the relevant reasoning here is that where fewer settlers went to stay, less of their human capital was brought and developed via educational systems (Lloyd et al. 1999: 17). Thus the idea is that the colonisers' initial human capital endowment and its proliferation affected long-term economic development. This links in with Krueger and Lindahl (2001:1105) who, reviewing the literature on education and growth, conclude that 'the initial level of education [is] positively correlated with economic growth'. For Africa, the corollary would be that '[1]ow levels of health and education are two salient factors contributing to [Africa's] slow growth', as Schultz (1999:67-68) notes.

Some observers question the relevance of education to growth, since the returns to education are typically low in agrarian societies (as most colonies were) relative to its return in more diversified economies (Galor et al. 2006, Pritchett 2000, Bennel 1996). For Africa at least, this is contradicted by the Appleton and Balihuta (1996) overview of studies on the link between education and agricultural productivity in Africa. They conclude that the estimated effects are positive and often very large economically (though not always statistically significant) (Appleton and Balihuta 1996: 420). But apart from 
this, the human capital school has emphasised that the key benefits of human capital are 'not technological but political' (Glaeser et al. 2004:282). Early writers argued that education 'broadens man's outlook, enables him to understand the need for norms of tolerance, restrains him from adhering to extremist doctrines, and increases his capacity to make rational electoral choices' (Lipset 1960:39). Educated people are purportedly more aware of government actions, more actively participating in society, and better able to organise themselves politically and to resolve their conflicts 'through negotiation and voting rather than through violent disputes' (Glaeser et al. 2004:272; also, Lipset 1960, Bourguignon and Verdier 2000, Tilly 1998). Education, in this view, is also a precondition for a well-functioning judicial and administrative system.

Yet other critics question this benign role of education in fostering economic growth and development, as it may also give rise to political instability, ethnic tensions and chronic violence. Huntington (1968:41) already observed that 'modernity breeds stability, but modernization breeds instability': he found that at low levels of literacy (roughly below $50 \%$ ), education breeds political instability while for countries with higher literacy rates it fosters stability. He went on to outline a mechanism where better educated people in developing countries with weak political systems are better able to organise protests, stage coups or foster other forms of political instability, which may impede economic growth. Bayly (2004:222) likewise writes of Britain's preference for indirect rule in Africa in an attempt to "stifle the growth of English-educated elites like those who were causing such troubles in India and Egypt'.

In another type of criticism, Bush and Santorelli (2000) document how education has been used by states for the purposes of cultural repression and segregation of ethnic minority groups. This includes colonial governments, who have used education for 
cultural assimilation aims and for divide-and-rule politics. For instance, in Belgian Africa, the schooling system from the late $19^{\text {th }}$ century 'openly favoured the Tutsi minority and actively discriminated against the Hutu' and during the 1920s 'set up special schools to educate Tutsis as the future leaders of the country and ... as support staff for the colonial government' (Bush and Santorelli, 2000:10). They link this to the enduring ethnic tensions in the successor states Rwanda and Burundi, which erupted into violence and genocide in the early 1990s. Bush and Santorelli provide similar examples from Sudan, South Africa, Uganda, Zaire and for many other, non-African countries. Likewise, Davidson (1992) describes how the fact that African elites were typically Western-style educated alienated them from their compatriots - one reason for the legitimacy crisis of African governments, which in turn has hampered sustainable growth processes. Also quantitative other research confirms that the relation of education with growth is not simple and typically nonlinear, often mediated by other variables such as inequality, as in Rehme's (2007) study.

This literature illustrates that education can indeed have long-term influence, for good as well as for harm. On balance however, these effects appear not sufficiently strong to make education's effect on economic growth negative on average. A large body of empirical research on that relation in the last half century finds that more and better education is robustly associated with higher levels of economic growth (Gemmel, 1996; Topel, 1999, Krueger and Lindahl, 2001), often conditional on other factors such as capital investment and the trade regime (Judson, 1998; Vinod and Kaushik, $2007^{1}$. Schultz (1999) presents an overview of findings relevant to Africa. Beyond this specialist literature, the role of education in creating the 'wealth of nations' is also a mainstay in 
the general study of factors fostering economic growth, from Adam Smith to David Landes' (1997) celebrated Wealth and Poverty of Nations.

We build on these results by looking back to colonial times. Taking our cues from the human capital literature, we hypothesise that colonial education may have fostered long-term growth through two channels: both by affecting present education levels, and through its effect on political institutions, fostering stability, 'voice', and good governance (especially, secure property rights and law and order). In support of this link, Lipset (1960) found that the least educated societies are never stable democracies, whereas highly educated societies generally are. This was updated and confirmed by Glaeser et al. (2004), who also find a strong effect of initial education on institutional changes.

It is important to note that we restrict our analysis to colonial education, and this is a limitation of the present research. Obviously, also pre-colonial, indigenous education systems - such as education by village elders, the extended family or in an indigenous religious setting (Adeyemi and Adeyinka, 2003) - invest people with social and cognitive skills and knowledge, and thus may build their human capital and so contribute to, among other things, economic growth. Or alternatively, they may have interacted with (hindered or fostered) the development of colonial education systems. Such indigenous education systems predated and often co-existed with colonial education efforts, and may have been important because the reach of colonial administration and education systems was often limited. As Bayly (2004:254) notes of colonial administration in general, '[w]hole areas of the European colonial world ... remained in the grip of resistance to central authority, and the power of local chieftains until the very beginnings of decolonization itself in the 1940s.' In this environment, state-colonial education systems must have been only one of 
many influences on human capital, and indigenous education systems may have been equally (or more?) determining to human capital formation as was colonial education..

But as indigenous education systems varied greatly over communities and were often not formalised, it is difficult to systematically take them into account in a quantitative cross-country analysis - even if there were reliable cross-country data. And even apart from data issues, also conceptually the impact of pre-colonial education on colonial education is a vast topic in itself, mediated and shaped as that relation is by environmental factors such as population density, the spread of Islam with its rival schooling system, and the different policies of colonisers (see also Lange et al. 2006). For reasons of scope and delineation we therefore consider it beyond this paper to treat it in any detail; but we return to this issue in our concluding section 5 as an avenue for future research.

We limit this study to a test of the effect of colonial human capital on subsequent growth in former African colonies. We do however include control variables (relating to legal origins, extractive institutions and geography). We will explicitly test in section 4 the two 'human capital' channels suggested in the literature. But first we turn to a consideration of the context. 


\section{Colonial and Post-Colonial Education and Development in Africa: Historical Background}

We organise our discussion of colonial education systems around the main distinction in our sample, which is the difference between educational policies by the British and the French colonising powers. The spread of European-style education in the territories they colonised was part of the late $19^{\text {th }}$ and early $20^{\text {th }}$ century process of empire building, in which the British and French vied for control over large parts of the African continent: formal education rates increased rapidly once the 'scramble for Africa' truly began in the 1880s, and indeed spread most quickly in contested areas. For instance Tanzania, handed to the British empire by the League of Nations after the First World War, and not threatened by the ambitions of rival colonisers, continued to have the lowest primary enrolment rates in all British Africa.

The two major European powers operated with distinct styles and educational outcomes. Benavot and Riddle (1988) calculate enrolment rates per school age population for different years before 1940, and find on average considerably higher figures in British Africa compared to French West Africa and Equatorial French Africa (see also Bowman and Anderson 1963). This difference in outcomes can be plausibly linked to the complex interaction, in both the French and British colonies, of their two most powerful institutions: the state, represented by the colonial administration system; and the church, represented by missionary educators. 


\subsection{Colonial Administration}

The British exercised 'indirect rule' in Africa (Lugard 1929), where traditional structures and institutions were left intact and colonial rulers attempted to work with traditional chiefs. Within the colonial superstructure, chiefs maintained direct power over their peoples and lands (Lugard 1919). Indirect rule was motivated by pragmatism and by the aim of reducing the costs of colonial administration (Bayly 2004:222), and was characterised by a relative tolerance towards local customs compared to other colonial powers (Lugard 1929 and Wesseling 1991, Lloyd et al. 1999). The British did not introduce one centralised educational policy in their colonies but instead largely left it to missionaries to provide the population with education and to decide whether to educate also in the vernacular (Crowder 1964).

Missionaries had already laid the foundation of the schooling system before colonisation properly started, and the British government realised that they where the only party who had the organisation (and the motivation) to 'bear the brunt of the work in the early period' (Cowan et al 1965: 3). This attitude changed only after the First World War, when the colonial administration faced increasing needs for an educated administrative workforce. In a policy memorandum published shortly after the First World War, the British government announced that it 'reserved to itself the general direction and supervision of educational policy' and that 'voluntary agencies should be used in education' to which grants in aid were to be made if they 'conformed to the established standards' (Cowan et al. 1965:6). The colonial government increasingly involved itself in the content of educational programmes as it used inspection and supervision to monitor the spending of its funds. This larger involvement was partly also a response to growing concerns in the internationally community - expressed particularly 
in the League of Nations - about the quality and accessibility of colonial education (Cameron 1970, Cowan et al. 1965).

The major aim of British colonial schooling, then, was to provide Africans with some minimal level of education and additionally build administrative capabilities of traditional chiefs (Lloyd et al. 1999, Sutton 1965). But education was not a ticket to upward mobility. Non ruling-class Africans who achieved higher education could not participate in the ruling of the colony (Collins 1970). Since the British wished to avoid an indigenous educated elite, colonial officials discouraged general education beyond the primary level. Cost considerations also played a role in the British administration preferring vocational training over general literacy and general education (Bayly 2004:222, Wesseling 1991).

In contrast, the French implemented an assimilation policy with the ultimate goal of providing non-Western peoples with 'cultural characteristics that would make them acceptable as citizens on the same basis as their European fellow at home' (Sutton 1965: 63), while 'degrading or ignoring [traditional] institutions in favour of French customs, culture and civilization' (Collins, 1970: 162). Assimilation policies implied the imposition of direct, centralized French control, including a centralised educational policy. By the beginning of the $20^{\text {th }}$ century all schools were obliged to teach in French and to adopt the French school curriculum (Lloyd et al. 1999, Cowan et al. 1965).

Also in contrast to the British, the French colonial government divested indigenous chiefs of their power by creating new administrative units (cantons) which typically cut through traditional boundaries. Chiefs did keep their nominal positions but were assigned to cantons on the basis of their education or demonstration of loyalty to the French (Crowder 1964). The reward to obtaining education was thus admittance to the 
lower echelons of the administration system (Collins 1970). Since most positions in the colonial administration were to be filled by French nationals, trained in France, the colonial government selected those who received advanced schooling with care, fearful of unemployed higher educated Africans. A small elite excepted, pupils in the French colonial schools received training in basic skills only (Lloyd et al. 1999).

Like the British colonial government, and largely for the same reasons, the French colonial government gradually increased its investments in education after the First World War. But until the end of the Second World War, the basic pattern established in the French colonies already by the turn of the century did not change (Cowan et al. 1965:9).

\subsection{Missionary Education}

Beginning in the $16^{\text {th }}$ century, missionaries had brought European-style education to Africa. During the first decades of colonisation, the British colonial government was mainly occupied with maintaining law and order and missionaries remained the only party active in providing formal education to African people in the British colonies (Cameron 1970). An additional factor for leaving education to the missionaries was the British desire, noted above, to contain the cost of colonial administration (Lugard 1929, Bayly 2004). In contrast, the French Third Republic (1870-1940) enshrined the separation of state and church in its constitution. While this was reflected in widespread antipathy towards missionary education in the colonies, in practice, this resentment was tempered by the government's recognition of the valuable role of missionary education in the government's assimilation agenda. So was created a dual church-state educational 
system, where missionary schools received state funding and functioned alongside state schools, adhering to the French state's centralised educational policy.

The presence of missionary (rather than only state) schools arguable helped the spread of Western-style education in the colonies. Both the Catholics in French Africa and the predominantly Protestant (Anglican, but also other) missionaries in British Africa realised, in the words of Bishop Joseph Shanahan, 'that those who hold the school hold the country, hold its religion, hold its future' (as cited by Berman 1975: 22). Between various churches, rivalry existed to reach as many people as possible. Helped by improved means of communication, this stimulated the rapid spread of missionary educational work in the first half of the $20^{\text {th }}$ century, with enduring results (Cameron 1970). In those former French colonies where the missionary school system was more developed (Madagascar, Central African Republic, Cameroon, the Congo and Gabon), the overall post-colonial enrolment rates were highest (Debeauvais 1964; and Benavot and Riddle, 1988). Missionary activity was even more determining to long-term educational achievements in British Africa, were education was largely the domain of the churches.

If the role of the churches within colonial education was markedly different between French and British Africa, so were the missionaries. Unlike Catholic educators, Protestants missionaries generally considered their presence temporary since they envisioned independent, self-reliant indigenous churches (Berman 1975). This vision required a relatively high standard of fairly broad-based education, from which a future African church leadership could emerge. Also, due to the larger emphasis on individual bible study in Protestant theology, Protestant missionaries placed more value on spreading the key skill of reading among the whole population. 
Both the colonial administration and the missionaries responded to most Africans' initially hostile reaction to Western education differently, depending on the nature of the local indigenous religion. In Muslim areas animosity to Western education was usually respected and educational efforts restricted or abandoned. Large parts of Western Africa were Islamicised already before the French arrival, and the French did not replace Islamic education with their own system. In contrast, areas with traditionally animistic religions were nearly all Christianised eventually, and schooling was an important instrument in the process.

This policy had long-term consequences. As an illustration, the animistic southern part of Nigeria was Christianised, while Christian missionary activity in the Muslim areas of Northern Nigeria was forbidden (Sutton 1965). In consequence, by 1958 over 90 percent of the southern children were enrolled in primary schools, in contrast to only 9 percent in the northern part (Ogunsheye 1965; Morgan and Armer 1988). As Benavot and Riddle (1988), Daun (200), Hanson II (1989) and Harrison (1988) show, colonial education in French Africa, more of which covers traditionally Muslim areas than was the case in British Africa, was clearly more restricted by this policy. Similarly, within the French areas, predominantly Muslim West Africa shows lower formal educational achievements compared to formerly animistic Equatorial Africa.

These differences in educational development have shown great stability over time (Brown 2000). African educational standards in colonial times ${ }^{2}$ correlate with Africa's educational achievements in $1995^{3}$, with an $\mathrm{R}^{2}$ of nearly 0.7 . The post-colonial African distributions of educational achievements have been so persistent in part because many kept strong linkages to their colonial foundation (Lloyd et al. 2000). Newly postcolonial independent government typically had limited resources and many challenges 
and therefore did not take on extensive educational reforms: they 'hesitated to take over in toto a system it had not the resources to run' as Cameron (1970: 25); and this reason for continuity has remained relevant since - see Brown (2000) and Ntiri (1993). This continuity lends partial support to our hypothesis that colonial education distributions had an enduring impact on growth patterns. In the next section we illustrate this claim by exploring the post-colonial development of educational systems in two countries: francophone Senegal and Anglophone Uganda.

\subsection{Educational Continuity and Economic Development Illustrated: Senegal and Uganda}

Senegal's newly independent government inherited in 1960 the centralised educational system characteristic of French colonies, with a relative large role for state-run schools. It developed a new education policy aiming at free, universal and compulsory education (Cain et al. 1994). Successive governments planned further reforms in 1969, 1979 and 1984 in order to develop a specifically African curriculum, to address issues of gender inequality and urban/rural inequalities, to promote instruction in a national language, and to provide more market-relevant skills. But as Evans (1994), Bakary (1995), and Cain et al. (1994) all document, few of these plans were actually implemented and much of the schooling system remained unchanged from the colonial period: most teaching is still in French and the curriculum is still French-style. Financial restraints and the entrenchment of elites benefitting from the status quo are among the reasons.

The allocation of educational resources in Senegal is heavily biased against rural people: 93 percent of urban children but only 10 to 34 percent of rural children were enrolled in schools during the 1990s (Cain et al. 1994). Senegal also has lower primary enrolment rates and higher secondary and tertiary enrolment rates than most francophone 
African countries (Evans 1994). Starting from very low literacy rates in 1960 when only 5 percent of the population could read, still in 1990 only 29 percent of adult population was literate, increasing to 39 percent in 2006 (UNESCO; World Development Indicators 2006). Thus education has retained it colonial features of exclusivism and strong elitism, mainly benefitting the better-off urban minority.

But despite these limitations and the relative inertia of the educational system since colonial times, there is evidence that Senegalese education is positively linked to economic development, for instance as measured by productivity in the manufacturing sector (accounting for around 18 percent of GDP) as Mbay (2002: 17) finds. Furthermore, Échevin and Murtin (2008:7) find that education is a productive input in all formal sectors as well as in the services and trade segments of the informal sector (which provides most employment in Senegal). Another education effect they find is that in informal firms, the employer's level of education is positively associated with employee wage levels.

In sum, the ex-French colony which is now Senegal has both retained many of the colonial features in its educational system and has seen a positive contribution of education to output, productivity and wage levels. The reach of its educational system has remained limited, and so has the rate of its economic growth.

In contrast to Senegal, the British colony which is now Uganda had a colonial primary school system predominantly run by churches (Cameron 1970). Although the colonial government increasingly funded these schools to support educational expansion, only 46 children per 1,000 population went to school around 1950. Soon after Uganda became independent, the new government attempted to implement a more centralised educational system compared to the decentralised system it inherited from the British 
(Cameron 1970). It also laid heavier emphasis on primary education - a policy which pushed up primary enrolment rates even in the 1970s and 1980s when Uganda went through serious economic and political turmoil. This trend was reinforced and accelerated when Museveni came to power in 1985, increasing the budget from the 10 percent it had been under the Amin government to 23 percent (Byrnes, 1990). Literacy rates consequently rose from 25 percent in 1974 to 56 percent in 1990 and on to 67 percent in 2006.

But many aspects of the Ugandan schooling system remain similar to the colonial system despite these reforms - as in Senegal, though not quite to the same extent. National exams determine the advancement from one level to the next, as is customary in the British system. The British curriculum remained in place until 1974, when it was replaced by a national curriculum. Instruction in local languages is common in the first few years of primary school in some regions (as it was during colonial times), but English is still the official language (Byrnes, 1990; StateUniversity, 2008).

As in Senegal, there is clear evidence that Uganda's economic performance is linked to its educational achievements. Empirical studies find that the increase in educational coverage from the mid-1980s is reflected in rising agricultural productivity and in higher wages. Appleton and Balihuta (1996) argue that both general skills (for example numeracy and literacy) and specific knowledge enabled farmers to better implement productivity-enhancing polices such as fertiliser and pesticide applications. Using Uganda's first nationally representative household survey, they find that the sum of the total years of primary schooling of farm workers increases farm output significantly. If farm workers had 4 years of schooling, output was 7 percent higher than if they had no schooling. Doubling the number of schooling years from seven to fourteen 
years (equivalent to an increase from one primary graduate to two graduates) led to an estimated increase in output of 13 to 19 percent compared to the no schooling alternative (Appleton and Balihuta 1996: 426). Schooling was also found to have spill-over effects, where farmers with better educated neighbours tended to be more productive themselves. The results also show that secondary schooling does not lead to growth in farm productivity, and that there is very large variation in the education effects across Uganda's regions (Appleton and Balihuta 1996: 424). Thus, this study finds that education can raise the productivity of farm workers in several ways.

Appleton (2001) in another study finds that better education is associated with higher levels of household welfare, the effect depending on the level of education and the household's portfolio of economic activities. Primary education is found to modestly raise the earnings in households engaged in agriculture, and more substantially raise earnings of households engaged in wage employment. It also opens up opportunities to move into nonagricultural self-employment. In contrast to Appleton and Balihuta (1996), secondary schooling is found to raise agricultural productivity as well as wage incomes. University education only has an effect on the earnings from wage employment. Beyond primary education levels, further education induces a trade-off between losses in agricultural and non agricultural self employment income and increases in wages (Appleton 2001: 20). Thus education is also instrumental in the structural transformation from an agrarian livelihood towards participation in an industrial or service oriented economy.

Summing up these two country narratives, in both Senegal and Uganda the legacy of colonial educational policies can still be discerned, especially in the value placed on universal (primary) education. While both countries officially adhere to the goal of 
providing universal education, only Uganda actually implemented policies to reach that goal while the Senegalese educational system remains more exclusivist and elitist. This parallels the more active British colonial polices towards a basic level of education for all (Lloyd et al. 2000) compare to the more passive French attitude to mass education. Uganda's educational expansion can be consistently linked to its impressive economic development over the last two decades, as Appleton (2001: 23) points out. In contrast in Senegal, Appleton and Teal (1999) argue, institutional restrictions and lack of investment in complementary factors of production (such as capital) have restricted the opportunities for many people to work in the formal sector. But given the positive educational returns to productivity observed in the informal sector by Échevin and Murtin (2008), Senegal's limited post-colonial increase in education did have a modest positive influence on its economic development. 


\section{Data and Analysis}

We use education data collected from the colonial yearbooks ${ }^{4}$ on the last years of African colonialism between 1945 and 1950 (Sudan was the first sub-Saharan country to gain independence in 1956) but before the European influence on the economic system started to decline (Hazlewood 1972; Giblin 1980; Hopkins 1973). Three variables from this data set are relevant to the present analysis:

(i) and (ii) the percentage of Europeans per total population and the number of Europeans per square mile. A salient feature of this newly compiled data are that in the 1940s, British colonies were on average about five times more densely populated than French colonies (27 as compared to 5 persons per square kilometre), but with $1 \%$ of the total population, the British presence was still about twice as large as the French who formed $0.5 \%$ of the population.

(iii) the number of primary and secondary pupils per 1,000 population, which proxies investment in educational institutions following for example Easterlin (1981). As already noted in section 2, the ratio of total pupils to the population were clearly higher in British colonies 5 .

The number of pupils per population will be our measure for educational human capital in colonial times. This measure is obviously not a perfect one - for instance, with its emphasis on coverage rather than quality it leaves important dimensions of colonial education unaccounted for. We therefore explored three alternatives in some detail. These are: the share of public investment from colonial budgets into the education system; literacy rates; and the pupils-to-teacher ratio as a proxy for educational quality. 
In each case we ran into very serious data difficulties. One conceptual problem with the measure of budget shares for education is that it is an input measure which is only indirectly linked to the output of colonial educational achievements, which we are interested in. Additionally it varies with variations in total budgets, which need not reflect variations of actual resources allocated to education. For instance, where more expenditure went to increases in teacher salaries, this does not necessarily reflect an increase in the coverage or quality of education (Lloyd et al. 1999). Likewise, in the years after the Second World war, colonial governments changed their policies towards Africa and focused more on development. This shift in policy involved substantial changes in the level of public expenditure, also directed at the social sector (Hopkins 1973; Hazlewood 1953/54). Measuring it consistently over countries is not really possible, as French and British (let alone other) definitions for budget components differed substantially. For instance, the French colonial government ran a general budget and a budget for each separate country it occupied; but the British did not. In brief, we judged it not possible to construct reliable data for educational budget shares in colonial times.

We found that the measure of pupil-to-teacher ratios, which would capture quality of education, was available for 15 countries only - ranging from 134 in Burkina Faso to 15 in Mauritania. While this limited number of observations disqualifies the variable from our statistical analysis below, it does seem that pupil-to-teacher ratios are clearly and negatively correlated to long term growth, as would be expected in the 'human-capital' view on Africa's long-term growth. The correlation coefficient of pupilto-teacher ratios with 1995 GDP per capita levels is -0.33 .

Similarly, the measure of literacy rates would arguably be a better variable than pupils per population, as it is a more direct measure of educational achievement. 
Unfortunately, to our knowledge literacy rates during colonial times are not available. The earliest literacy rates for only 19 sub-Saharan countries are available for 1960 . This is 'too little, too late': only 19 observations from a time well after decolonialisation had started. Still, there is considerable correlation between our measure of pupils per population and literacy rates in 1960 (correlation coefficient 0.49). Moreover, correlation between literacy rates in 1960 and in 1990 and 2006 are 0.71 and 0.62 respectively, whereas correlation between pupils per population and literacy rates in 1990 and 2006 are 0.72 and 0.69 respectively. In summary, pupils per population is the only variable for educational achievement that we could credibly construct from the colonial data; but the above explorations suggest that it also captures literacy levels.

We apply these data to the question of Africa's long-term growth in two ways. First, we explicitly check the two intervening steps in the Acemoglu et al. (2001) argument that higher settler mortality led to colonies being more thinly settled by Europeans and that a lower density of Europeans in the population led to different institutions, worse for long-term growth. Acemoglu et al. (2001) argue this based on the literature but without primary empirical evidence. In Table 1 we show that both these relations cannot be detected for sub-Saharan Africa. This then leads us to the second application, to explore an alternative explanation for Africa's long-term growth in an instrumental-variable estimation, using our measure of pupils per population.

In Panel A of table 1 we report results from regressions of the density of Europeans in the population and density of Europeans per surface measure on settler mortality. Neither regression gives statistically significant results, and the negative $\mathrm{R}^{2}$ indicate that models A1 and A2 perform worse than a constant-only model. In Panel B 
we regress the two index measures for colonial institutions used by Acemoglu et al. $(2001)^{6}$ on the density of Europeans in the population, and again fail to find a relation.

Table 1: The Links from Settler Mortality to European Densities to Institutions in Africa.

\begin{tabular}{|c|c|c|}
\hline Independent: & Europeans/population & Europeans/km2 \\
\hline settler & -0.000 & 0.000 \\
\hline & $(0.001)$ & $(0.007)$ \\
\hline (constant) & $\begin{array}{c}0.005 \\
(0.007)\end{array}$ & $\begin{array}{c}0.021 \\
(0.040)\end{array}$ \\
\hline $\mathrm{R} 2$ & -0.06 & -0.06 \\
\hline $\mathrm{N}$ & 18 & 18 \\
\hline
\end{tabular}

Panel B: Institutional quality is not explained colonial density of Europeans

\begin{tabular}{lllll} 
Independent: & 'Democracy' & 'Democracy' & $\begin{array}{l}\text { 'Constraints on } \\
\text { executive' }\end{array}$ & $\begin{array}{l}\text { 'Constrain } \\
\text { executive' }\end{array}$ \\
Europeans/pop & $\begin{array}{l}88.665 \\
(53.862)\end{array}$ & & $\begin{array}{l}49.778 \\
(36.587)\end{array}$ & \\
Europeans/km2 & & $\begin{array}{l}15.641 \\
(9.902)\end{array}$ & & 7.691 \\
(constant) & $2.078^{* * *}$ & $\begin{array}{l}2.078^{* * *} \\
(0.720)\end{array}$ & $3.104 * * *$ & $(0.778)$ \\
& $(0.709)$ & $(0.72)$ & $(0.493)$ \\
R2 & 0.069 & 0.061 & 0.036 & 0.012 \\
$\mathrm{~N}$ & 24 & 24 & 24 & 24 \\
\hline
\end{tabular}

Source: Settler mortality: Acemolgu et al. (2001), institutional variables: Polity IV, and authors' calculations. Standard errors are in parentheses.

These results in an African sample differ from those reported by Acemoglu et al. (2001) in a global sample of former colonies. This leads us to question the link between settler mortality and early institutions. While Acemoglu et al. (2001, footnote 21) report that there is a 'weaker relationship between settler mortality and institutions in a sole Africa sample', we actually find no relationship in an African sample. Naturally, our sample size 
is necessarily small, especially for panel A results, and this may (partly) cause the lack of statistical significance. But at the least we conclude that there is no evidence that African colonial-era institutions are well proxied by settler mortality ${ }^{7}$.

This is not to say that there cannot be a link between settler mortality and African growth, or that institutions are irrelevant in this relation; only that the account of this link presented by Acemoglu et al. (2001) finds no support in the African data. Alternatively, settler mortality may have influenced other aspects of colonial institutions than its extractiveness. We noted in section 2 above that one candidate for an alternative channel is colonial human capital. Glaeser et al. (2004), Djankov et al. (2003) and Lipset (1959, 1960) suggested that colonial human capital may have influenced both colonial institutions and current human capital, and - through either or both of these channels - it may affect present GDP levels. It is this explanation of Africa's long-term growth that we will now explore empirically.

We start with an Ordinary Least Squares (OLS) specification where we regress our human capital variable PUPILS (per 1,000 population) on PPP per capita GDP levels in $1995^{8}$. We test robustness to other explanations by adding a legal-origin variable (COLONISER, which takes value 1 for British and 0 for French colonies) and up to four geographical variables from the following set: MALARIA (index of 1994 malaria prevalence), COASTPOP (the share of the population living within $100 \mathrm{~km}$ from the coast), LANDLOCKED 9 (absence of overland access to sea), TROPICS (the share of territory located in the tropics) ${ }^{10}$ and HYCROCARBONS (proven reserves of natural gas and crude oil in 1993, BTUs per person). In selecting these variables, we follow La Porta et al. (2004) and Gallup et al. (1998). We take out one of these variables in turn and in Table 2 reports OLS estimation results. We find that in four of the seven specifications, 
PUPILS significantly correlates with 1995 per capita GDP. Apparently OLS results are not robust to adding control variables; in addition, as noted they are plausibly biased because of endogeneity. Only MALARIA is consistently correlated with lower 1995 income levels.

Table 2: OLS regressions of Colonial Education and Controls on 1995 GDP per capita

\begin{tabular}{|c|c|c|c|c|c|c|c|}
\hline & $(1)$ & (2) & (3) & (4) & (5) & (6) & (7) \\
\hline PUPILS & $\begin{array}{l}7.679^{\star *} \\
(3.708)\end{array}$ & $\begin{array}{l}7.011^{*} \\
(3.691)\end{array}$ & $\begin{array}{l}8.266^{*} \\
(4.000)\end{array}$ & $\begin{array}{l}4.673 \\
(3.848)\end{array}$ & $\begin{array}{l}8.446^{* *} \\
(3.949)\end{array}$ & $\begin{array}{l}7.115 \\
(4.644)\end{array}$ & $\begin{array}{l}4.158 \\
(3.288)\end{array}$ \\
\hline COLONISER & $\begin{array}{l}-0.246 \\
(0.283)\end{array}$ & $\begin{array}{l}-0.244 \\
(0.255)\end{array}$ & $\begin{array}{l}-0.302 \\
(0.264)\end{array}$ & $\begin{array}{l}-0.203 \\
(0.265)\end{array}$ & $\begin{array}{l}-0.282 \\
(0.267)\end{array}$ & $\begin{array}{l}-0.256 \\
(0.297)\end{array}$ & \\
\hline MALARIA & & $\begin{array}{l}-1.235^{\star *} \\
(0.466)\end{array}$ & $\begin{array}{l}-1.065^{\star *} \\
(0.470)\end{array}$ & $\begin{array}{l}-0.933^{* *} \\
(0.406)\end{array}$ & $\begin{array}{l}-1.309^{\star *} \\
(0.483)\end{array}$ & & $\begin{array}{l}-1.357^{* \star *} \\
(0.464)\end{array}$ \\
\hline COASTPOP & & $\begin{array}{l}0.776^{*} \\
(0.439)\end{array}$ & $\begin{array}{l}0.560 \\
(0.643)\end{array}$ & $\begin{array}{l}1.128 \\
(0.672)\end{array}$ & & $\begin{array}{l}1.141 \\
(0.769)\end{array}$ & $\begin{array}{l}0.884 \\
(0.605)\end{array}$ \\
\hline TROPICS & & $\begin{array}{l}1.004 \\
(0.814)\end{array}$ & $\begin{array}{l}1.002 \\
(0.853)\end{array}$ & & $\begin{array}{l}1.257 \\
(0.827)\end{array}$ & $\begin{array}{l}-0.181 \\
(0.795)\end{array}$ & $\begin{array}{l}0.929 \\
(0.798)\end{array}$ \\
\hline HYDROCARBC & DNS & $\begin{array}{l}0.047 \\
(0.031)\end{array}$ & & $\begin{array}{l}0.055 \\
(0.040)\end{array}$ & $\begin{array}{l}0.033 \\
(0.037)\end{array}$ & $\begin{array}{l}0.028 \\
(0.043)\end{array}$ & $\begin{array}{l}0.046 \\
(0.033)\end{array}$ \\
\hline LANDLOCK & & & $\begin{array}{l}-0.239 \\
(0.361)\end{array}$ & $\begin{array}{l}0.186 \\
(0.448)\end{array}$ & $\begin{array}{l}-0.325 \\
(0.298)\end{array}$ & $\begin{array}{l}0.155 \\
(0.503)\end{array}$ & $\begin{array}{l}0.008 \\
(0.372)\end{array}$ \\
\hline (constant) & $\begin{array}{l}7.084^{\star \star \star} \\
(0.193)\end{array}$ & $\begin{array}{l}7.044^{\star * \star} \\
(0.725)\end{array}$ & $\begin{array}{l}6.933^{\star * \star} \\
(0.763)\end{array}$ & $\begin{array}{l}7.686^{\star \star \star} \\
(0.482)\end{array}$ & $\begin{array}{l}7.100^{\star \star *} \\
(0.762)\end{array}$ & $\begin{array}{l}6.978^{\star \star \star} \\
(0.845)\end{array}$ & $\begin{array}{l}7.136^{\star \star \star} \\
(0.711)\end{array}$ \\
\hline $\begin{array}{l}\mathrm{R} 2 \\
\mathrm{~N}\end{array}$ & 30 & 28 & 28 & 28 & 28 & 28 & 33 \\
\hline
\end{tabular}

Sources: Geographical data: Gallup et al (1998), Settler mortality data: Acemoglu et al. (2001), Colonizer data: La Porta et al. (2004), pupil data: authors' calculations. Standard Errors in parentheses.

Since the above analysis faces the same endogeneity challenges as the Acemoglu (2001) account, the question is whether the findings are robust to an alternative approach, addressing the endogeneity problem. We instrumented the colonial-era education 
measure PUPILS (the percentage of pupils in the population) with settler mortality SETTMORT around 1800, as in Acemoglu et al. (2001). We then regress this instrumented human capital variable on PPP per capita GDP levels in $1995^{11}$. Panel A in table 3 presents the second stage IV regression ${ }^{12}$. Panel B reports the corresponding first stage results. We test robustness to other explanations by adding controls, as above. We include not more than five variables in total because of the limited number of observations (23) in this instrumented-variable regression ${ }^{13}$. 


\begin{tabular}{|c|c|c|c|c|c|c|}
\hline & (1) & (2) & (3) & (4) & (5) & (6) \\
\hline \multicolumn{7}{|c|}{$\begin{array}{c}\text { Panel } \mathrm{A}-2^{\text {nd }} \text { stage of } 2 \mathrm{SLS} \text { : regressing } \ln \text { GDPpc in } 1995 \text { on PUPILS (instrument: settler } \\
\text { mortality)and controls }\end{array}$} \\
\hline PUPILS (INST) & $\begin{array}{l}31.504 * * * \\
(11.759)\end{array}$ & $\begin{array}{l}28.220 * * * \\
(8.767)\end{array}$ & $\begin{array}{l}23.612 * \\
(13.918)\end{array}$ & $\begin{array}{l}26.590 * * \\
(13.244)\end{array}$ & $\begin{array}{l}27.863 * * \\
(13.012)\end{array}$ & $\begin{array}{l}30.144 * * \\
(11.853)\end{array}$ \\
\hline COLONIZER & $\begin{array}{l}-0.593 * * \\
(0.302)\end{array}$ & $\begin{array}{l}-0.550 * * \\
(0.268)\end{array}$ & $\begin{array}{l}-0.502 * \\
(0.269)\end{array}$ & $\begin{array}{l}-0.556^{*} \\
(0.291)\end{array}$ & $\begin{array}{l}-0.570^{* *} \\
(0.285)\end{array}$ & $\begin{array}{l}-0.606 * * \\
(0.290)\end{array}$ \\
\hline MALARIA & & $\begin{array}{l}-0.683^{*} \\
(0.389)\end{array}$ & $\begin{array}{l}-0.701 * \\
(0.398)\end{array}$ & $\begin{array}{l}-0.744^{*} \\
(0.447)\end{array}$ & $\begin{array}{l}-0.709 * \\
(0.376)\end{array}$ & \\
\hline \multicolumn{2}{|c|}{ HYDROCARBONS } & $\begin{array}{l}0.034 \\
(0.030)\end{array}$ & $\begin{array}{l}0.012 \\
(0.041)\end{array}$ & $\begin{array}{l}-0.001 \\
(0.039)\end{array}$ & & $\begin{array}{l}-0.025 \\
(0.035)\end{array}$ \\
\hline COASTPOP & & & $\begin{array}{l}0.288 \\
(0.709)\end{array}$ & & & \\
\hline LANDLOCKED & & & & $\begin{array}{l}-0.207 \\
(0.342)\end{array}$ & $\begin{array}{l}-0.177 \\
(0.370)\end{array}$ & $\begin{array}{l}-0.193 \\
(0.353)\end{array}$ \\
\hline (constant) & $\begin{array}{l}6.536 * * * \\
(0.308)\end{array}$ & $\begin{array}{l}7.244 * * * \\
(0.504)\end{array}$ & $\begin{array}{l}7.264 * * * \\
(0.532)\end{array}$ & $\begin{array}{l}7.347 * * * \\
(0.704)\end{array}$ & $\begin{array}{l}7.281 * * * \\
(0.614)\end{array}$ & $\begin{array}{l}6.593 * * * \\
(0.374)\end{array}$ \\
\hline R2 (\%) & 25 & 37 & 46 & 31 & 27 & 34 \\
\hline $\mathrm{N}$ & 30 & 28 & 28 & 28 & 28 & 33 \\
\hline
\end{tabular}

Panel B $-1^{\text {st }}$ stage of 2SLS: regressing PUPILS on settler mortality and controls

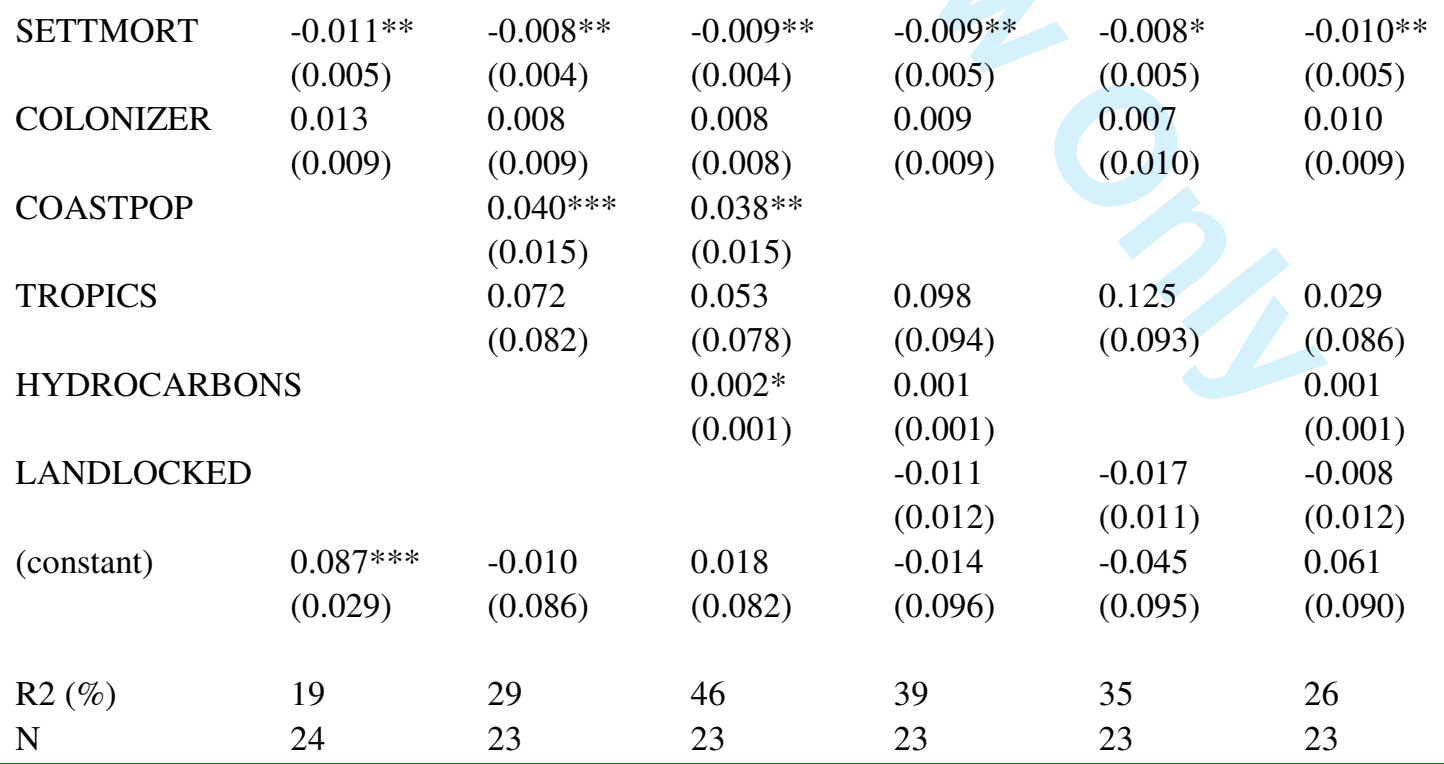

Sources: Geographical data: Gallup et al (1998), Settler mortality data: Acemoglu et al. (2001), Colonizer data: La Porta et al. (2004), pupil data: authors' calculations. Standard Errors in parentheses. 
In model (1) we include only a colonial origin variable. In model (2) we add MALARIA and HYDROCARBONS, in model (3) also COASTPOP. In model (4) we replace COASTPOP with LANDLOCKED and in models (5) and (6) we run this model without HYDROCARBONS and MALARIA, respectively. We similarly vary control variables in the first stage equation. We find that variation in specification affects the model fit as expected, but not the key results. Panel B shows a significant negative effect of settler mortality on colonial education levels in all models, supporting the panel A specification $^{14}$. And panel A shows that the instrumented PUPILS variable is positive associated with 1995 GDP levels in all specifications.

We conclude that the link between settler mortality and GDP in 1995, which Acemoglu et al. (2001) conjectured to run through 'extractive institutions', in Africa is most likely to run through human capital investments made in the colonial era through education $^{15}$. This conclusion is robust to including controls for geography and legal origin. It connects to the description given by Acemoglu et al. (2001: 1374-1375) of extractive institutions as inter alia involving low educational and healthcare investments; but in view of the lack of support for the intervening steps in the Acemoglu et al. (2001) argument, presented in table 1 , this interpretation is tenuous for the African setting. A more plausible understanding of the findings is to see them as support for the hypothesis that human capital, as distinct from the broader framework of production-and-commerce oriented institutions, was the more important factor for long-term growth (Glaeser et al., 2004). This view finds additional support in the lack of significant findings for institutional measures, such as 'democracy' and 'constraints on the executive' variables, reported in table 1. 
In addition, our estimates offer support for the legal-origin explanation of growth: the coefficient is negative and significant, implying that British colonization is correlated with lower 1995 income levels than is French colonization ${ }^{16}$. However, the significance of this exogenous variable is not robust to an OLS specification in Table 2, perhaps because COLONISER captures some other systemic difference between British and French colonies other than legal origin; for instance, the qualitative differences in education systems noted in section 3. Another explanation is offered by Joireman (2006) who observes significant heterogeneity with respect to colonial and post-colonial legal experiences within the group of British (ex-) colonies. This reality may undermine a single 'COLONISER' effect. Of the geographical variables, MALARIA is a robustly negative influence on growth, both in OLS and IV specifications.

Having established a robust relation of colonial education with current per capita income levels, we now pursue the 'educational' line of reasoning further by examining the additional hypotheses that (i) colonial education achievements persisted (that is that colonial education achievements statistically 'cause' present educational levels) and that (ii) colonial human capital caused colonial institutions. On (i), table 4 shows that instrumented education levels in the 1940 s correlate to present enrolment rates, both primary and secondary ${ }^{17}$. Thus, a first channel through which exogenous, colonial-era investments in human capital have affected present growth is through the "persistence effect' mentioned above, by durable increases in levels of human capital till the present. It is important to note that human capital persisted over time, while institutional measures did not, as discussed above. This is in contradiction to the argument put forward by Acemoglu et al. (2001) on the durability of institutional quality, but it is in line with the 
Glaeser et al. (2004:274) argument that human capital is 'the more basic cause of growth'.

Table 4: Colonial Human Capital Persisted

IV regression of colonial human capital on present human capital

Panel A - Second stage of 2SLS: regressing PUPILS (instrument: settler mortality)

on primary and secondary enrolment rates in 1995

$2^{\text {nd }}$ stage dependent: $\quad$ PRIM95 SEC95

Constant $0.843 * * \quad-0.096$

$(0.342) \quad(0.206)$

PUPILS 35.634*** 15.060***

$(9.246) \quad(5.561)$

first stage dependent: PUPILS PUPILS

Panel B - First stage of 2SLS: regressing settler mortality on PUPILS

Constant

$0.111 * * *$

$0.111^{* * *}$

(0.032)

$-0.013 * *$

(0.032)

SETTMORT

$(0.005)$

$-0.013 * *$

(0.005)

Obs.

$\mathrm{R}^{2}$

19

19

0.63

0.49

Source: education data: Barro and Lee (2001), settler mortality data: Acemoglu et al (2001), pupils data: colonial yearbook and authors' calculations. Standard errors are in parentheses.

Finally in table 5 we explore another channel by examining the influence of human capital investments on contemporaneous institutional indicators. We consider 
institutional indices both on democracy and on constraints on the executive as used by Acemoglu et al. (2001), and find positive and significant correlations of PUPILS with both in an OLS framework. These findings are however not robust to using instrumented education, so that the results may be partly driven by endogeneity of education to institutions $^{18}$. We conclude that the major channel through which colonial education affects current growth is though the persistence effect in educational quality, more than through institutional quality.

Table 5: Colonial Education and Current Institutions

\begin{tabular}{lcc}
\hline \multicolumn{3}{c}{ OLS regression of current institution on colonial education levels } \\
\hline Dependent: & DEMOCRACY75 & CONSTRAINT \\
Constant & 1.154 & $2.641^{* * *}$ \\
& $(0.733)$ & $(0.501)$ \\
PUPILS & $37.990 * * *$ & $19.086^{* *}$ \\
& $(13.346)$ & $(9.133)$ \\
& & \\
$\mathrm{N}$ & 37 & 37 \\
$\mathrm{R}^{2}$ & 0.16 & 0.09
\end{tabular}

Source: institutional data: Polity IV, pupil data: author's calculations. Standard Errors in parentheses. 


\section{Summary, Future Research and Conclusions}

Acemoglu et al. (2001) conjecture that high settler mortality led colonising powers to introduce 'extractive 'institutions, which set the economy on a long-term path of low and volatile growth. Low settler mortality, in contrast, supposedly caused colonisers to build institutions more conducive to growth. When we implement this analysis for a sample of only African countries, both these correlations disappear. Higher settler mortality did not lead to African colonies being more thinly settled by Europeans, and a lower density of Europeans in the population did not lead to different institutions, worse for long-term growth. While it is noteworthy that these findings might well be due to small sample size, they leave sufficient room to pursue an alternative explanation of long-term growth differences between African countries, based on colonial education rather than colonial extractive institutions. We collect archival material from colonial yearbooks to construct a novel data set on European and total population densities and investments that the colonial powers made in schooling.

In our analyses we find that African colonial education does possess both properties ascribed to institutions in the global Acemoglu et al (2001) study: it correlates well both with settler mortality and with current measures for human capital. Instrumenting education with settler mortality, we obtain again a robust explanation of long-term development which does not suffer from endogeneity and which is specific to Africa. We establish the robustness of this explanation by introducing controls for the legal origin of institutional systems and for a number of geographical variables, both of which have additional explanatory power. Further investigation of the channels through which education fostered growth suggests its positive impact on both current education 
and on colonial institutions, though the causality between colonial institutions and colonial education seems two-way.

There are several loose ends to this study, which provide opportunities for future research. A big one relates to a relatively neglected issue in this strand of literature: what was there before colonialism ${ }^{19}$ ? Obviously pre-colonial Africa was not tabula rasa with respect to education. A next step is this literature would therefore be to enlarge the scope of analysis one step further compared to the Acemoglu et al. (2001) and similar frameworks (including this one) by noting that long-term growth may have depended not only on colonial education, but also on pre-colonial African education levels. In line with the human capital definition, this would include organized efforts by Africans to create or pass on skills and knowledge that contributed to long-term growth of their economies either directly or by providing a basis for colonial education systems to be more rapidly or slowly. One might conjecture, for instance, that peoples used to education of some sort were more willing to have their children attend colonial schools; or conversely, that indigenous and colonial education were rivals and so the presence of pre-colonial education hampered the spread of colonial education. But as in the present study, a simple causal approach would be amiss in that it ignores an endogeneity problem similar to the one addressed in this paper. Namely, pre-colonial education cannot be assumed to simply determine (positively or negatively) colonial education; instead, both are plausibly jointly caused by underlying factors.

In light of the literature reviewed in this paper, one might speculate about two strong candidates for this underlying factor: Islam and population density. Societies were Islam - a 'religion of the book' - had spread before Western colonisation arrived, were more likely to have more extensive pre-colonial formal schooling systems and higher 
literacy levels. Bayly (2004:261), writing on pre-colonial states, observes that in Muslin West Africa, the state crept forward in alliance with elite literacy and the spread of purist Islam'. At the same time, as we noted in section 3, colonisers restricted colonial education in Islamic areas. So 'Islam' may well be a factor jointly fostering pre-colonial and hindering colonial education systems. A second candidate for the underlying factor is population density, which is one sign of a society's potential for economic and social development, including the development of schooling systems. Population density may also be systematically related to origin of the coloniser. We learn this, for instance, from Lange et al. (2006) who explain that 'Britain tended to colonize most extensively precolonial regions that were sparsely populated and underdeveloped' ( $\mathrm{p}$ 1412). This is in comparison to the Spanish; in our data we detect that British colonies (mostly in east Africa) were far more densely populated than other, predominantly French colonies, many in arid West Africa. The densities are 27 and 5 persons per square kilometre, respectively, and the correlation coefficient between population density and British origin is a high +0.26 . In section 3 we describe how Britain also achieved higher enrolment rates in its colonial schools than did the French, partly by making more use of missionary education. Combining these facts, we have again that population density is an influence both on colonial education and on pre-colonial education - in this case, both influences are positive.

In light of these supposed two underlying factors, 'Islam' and 'population density', with opposite effects on pre-colonial education, a further observation is that precolonial education itself is far from homogeneous. The most important distinction may well be between types of pre-colonial education linked to the spread of Islam and with more emphasis on formal schooling and literacy; and informal, indigenous pre-colonial 
education which had developed in Africa itself, plausibly in settled communities with high population densities. Valuable follow-up research would be to investigate how different kinds of pre-colonial education affected colonial education, and so indirectly shaped the long-term economic fortunes of Africa.

This is an avenue for future research. The contribution of this study was to suggest and substantiate that African colonial education levels are among the long-term determinants of African economic growth. A more general implication is that the humancapital explanation of growth appears a fruitful issue to be explored in the development literature. 


\section{References}

Acemoglu, D., Johnson, S., Robinson, J.A. (2001) 'The Colonial Origins of Comparative

Development: An Empirical Investigation', American Economic Review, 91 (5), pp.

$1369-1401$.

Acemoglu, D., Johnson, S., Robinson, J.A. (2002) 'Reversal of Fortune: Geography and Institutions in the Making of the Modern World Income Distribution', Quarterly Journal of Economics, 117 (4), pp. 1231-1294.

Adeyemi, M.B and Adeyinka A.A. (2003) 'The Principles and Content of African Traditional Education', Education Philosophy and Theory, 35 (4), pp. 425-440.

Appleton, S. (2001) 'Education, Incomes and Poverty in Uganda in the 1990s' CREDIT research paper $01 / 22$, University of Nottingham.

Appleton, S. and Balihuta, A.A (1996) 'Education and Agricultural Productivity: Evidence from Uganda', Journal of International Development, 8 (3), pp. 415-444.

Appleton, S. and Teal, F. (1999) 'Human Capital and Economic Development' Background paper prepared for he African Development Report 1998.

Bakary, T.D. (1995) 'Educational Systems, Social Stratification and the Construction of the State' in Kirk-Green, A. and Bach, D. (eds) State and Society in Francophone Africa since Independence. London: Macmillan Press Ltd.

Bardhan, P. (1993) 'Symposium on Democracy and Development', Journal of Economic Perspectives, 7 (3), pp. 45-49.

Barro, R. J., and Lee, J.W. (2001) 'International Data on Educational Attainment: Updates and Implications', Oxford Economic Papers, 53, pp. 541-63.

Barro, R.J. (1996) 'Democracy and Growth', Journal of Economic Growth, 1, pp. 1-27. 
Barro, R.J. and Lee, J.W. (1993) 'International Comparisons of Educational Attainment', NBER Working paper 4349.

Bayly, C. (2004) The Birth of the Modern World. Oxford: Blackwell

Benavot, A. and Riddle, P. (1988) 'The Expansion of Primary Education, 1870-1940:

Trends and Issues', Sociology of Education, 61 (3), pp. 191-210.

Bennel, P. (1996) 'Rates of return to education: does the conventional pattern prevail in Sub-Saharan Africa?', World Development, 24 (1), 183-199.

Berman, E.H. (1975) 'Christian Missions in Africa', in: E.H. Berman (ed) African Reactions to Missionary Education, Colombia University, pp. 1-53.

Bloom, D.E. and Sachs, J.D. (1998) ‘Geography, Demography, and Economic Growth in Africa', Brookings Papers on Economic Activity 2:1998.

Bourguignon, F. and Verdier, T. (2000) 'Oligarchy, Democracy, Inequality, and Growth', Journal of Development Economics, 62, pp. 285-313.

Bowman, M.J. and Anderson, C.A. (1963) 'Concerning the Role of Education in Development' in: C. Geertz (ed) Old Societies and New States, London: CollierMacMillan Ltd., pp. 245-279.

Brown, D.S. (2000) 'Democracy, Colonization, and Human Capital in Sub-Saharan Africa', Studies in Comparative International Development, 35 (1), pp. 20-40.

Burkhart, R.E. and Lewis-Beck, M.S. (1994) 'Comparative Democracy: The Economic Development Thesis', the American Political Science Review, 88.

Bush, K. and Saltarelli D. (2000) The Two Faces of Education in Ethnic Conflict. Florence: UNICEF Innocenti Research Centre.

Rita M. Byrnes (ed) (1990) Uganda: A Country Study. Washington: GPO for the Library of Congress. http://countrystudies.us/uganda/35.html 
Cain, J., Schuman, S., VanBelle-Prouty, D. and Duerbeck, D. (eds.) (1994) 'Lessons

Learned on the Integration of Health, Population, Environment, Democratization, and

Privatization into Basic Education Curriculum in Africa' Technical Paper, 14, Creative

Associates International, Inc., Washington DC.

Cameron, J. (1970) The Development of Education in East Africa, Columbia: Columbia

University Press.

Clignet, R.P. and Foster, P.J. (1964) 'French and British Colonial Education in Africa', Comparative Educational Review, 8 (2), pp. 191-198.

Coleman, J.S. (1965) 'Introduction: Education and Political Development' in: J.S. Coleman (ed) Education and Political Development, Princeton University Press, pp. 150.

Collier, P. and Gunning, J.W. (1999), 'Why has Africa Grown Slowly?', Journal of Economic Perspectives, 13 (3), pp.3-22.

Collins, R.O. (1970) 'Problems in the History of Colonial Africa 1860-1960', PrenticeHall, Inc, Englewood Cliffs, N.J.

Cowan, L.G., O’Connell, J. and Scanlon, D.G. (eds.) (1965) Education and NationBuilding in Africa, New York: Frederick A. Praeger.

Crowder, M. (1964) 'Indirect Rule - French and British Style' in: R.O. Collins (ed) Problems in The History of Colonial Africa 1860-1960, (1970), Prentice-Hall, Inc, Englewood Cliffs, N.J, pp. 211-219.

Daun, H. (2000) 'Primary Education in Sub-Saharan Africa- a moral issue, an economic matter, or both?', Comparative Education, Vol. 36 (19), pp. 37-53.

Davidson, B (1992) The Black Man's Burden. New York: Three Rivers Press. 
Debeauvais, M. (1964) 'Education in Former French Africa', in: J.S Coleman (ed) Education and Political Development, (1965), Princeton University Press, pp. 75-91. Dewey, J. (1916) 'Democracy and Education', The Macmillan Company (electronic resource was consulted, published 199?, Campaign, Ill.).

Diamond, J. (1999) 'Guns, Germs and Steel: the Fates of Human Societies', W.W. Norton.

Djankov , S., Glaeser, E.L., La Porta, R., Lopez-de-Silanes, F., Shleifer, A. (2003) 'The New Comparative Economics', Journal of Comparative Economics, 31, pp. 595-619. Djankov, S., La Porta, R., Lopez-de-Silanes, F., Shleifer, A. (2002) 'Courts: The Lex Mundi Project', NBER Working Paper 8890.

Easterlin, R.A. (1981) 'Why Isn't the Whole World Developed?' Journal of Economic History, 41 (1), pp. 1-19.

Easterly, W. and Levine, R. (1997) ‘Africa’s growth tragedy: policies and ethnic divisions', Quarterly Journal of Economics, 112, (4), pp. 1203-1250.

Easterly, W. and Levine, R. (1997) 'Africa's Growth Tragedy: Policies and Ethnical divisions', The Quarterly Journal of Economics, November 1997.

Échevin, D. and Murtin F. (2008) 'What Determines Productivity in Senegal? Sectoral Disparities and the Dual Labour Market', GRÉDI working paper 07-15.

Evans, D.R. (1994) 'Education Policy Formation in Africa: A Comparative Study of Five Countries', Technical Paper, 12, IDCA, Washington DC.

Gallego, F.A. (2006) 'Historical Origins of Schooling: The Role of Political Decentralisation', Working Paper. 
Gallup, J.L., Sachs, J.D, and Mellinger, A.D. (1998) 'Geography and Economic Development', NBER Working Paper 6849.

Galor, O., Maov, O. and Vollrath, D. (2005) 'The Emergence of Human Capital Promoting Institutions in the Process of Development', Working Paper .

Gardner, P. (2005), 'A Characterisation of Growth in Sub-Saharan Africa', ERN Economic Growth WPS, 6 (55).

Gemmel, N. (1996) 'Evaluation the Impacts of Human Capital Stocks and Accumulation on Economic Growth: Some New Evidence', Oxford Bulletin of Economics and Statistics 58 (1), pp. 9-28.

Giblin, J. (1980), 'The Image of the Loyal African during World War II and its Post war Use by the French Communist Party', Canadian Journal of African Studies, 14 (2), pp. 319-326.

Glaeser, E.L. and Shleifer, A. (2002) 'Legal Origins', Quarterly Journal of Economics, 117 (4), pp. 1193-1229.

Glaeser, E.L., La Porta, R., Lopez-de-Silanes, F. and Shleifer, A. (2004) 'Do Institutions Cause Growth?', Journal of Economic Growth 9, pp. 271-303.

Glaeser, E.L., Ponzetto, G., Schleifer, A. (2006) 'Why Does Democracy Need Education?', NBER Working Paper 12128.

Greene, W. (2003) 'Econometric Analysis', Englewood Cliffs, N.J.: Prentice Hall.

Hanson II, J.R. (1989) 'Education, Economic Development, and the technology Transfer: A colonial Test', The Journal of Economic History, 49 (4), pp. 939-957.

Harrison, C. (1988) 'France and Islam in West Africa, 1860-196o', Cambridge: Cambridge University Press. 
Hazlewood, A. (1953-1954), 'Colonial External Finance Since the War', The review of Economic Studies, 21 (1), pp. 21-52.

Huber, E., Rueschemeyer, D. and Stephens, J.D. (1993) 'The Impact of Economic Development on Democracy', Journal of Economic Perspectives, 7 (3), pp. 71-85.

Huntington, S. (1968) Political Order in Changing Societies. New Haven and London: Yale University Press

IMF, World Economic Outlook database (2004), Washington DC: the IMF.

Inkeles, A. and Sirowy, L. (1990) 'The Effects of Democracy on Economic Growth and Inequality: A Review', Studies in Comparative International Development, 25, pp. 126157.

Isham, J., Woolkock, M., Pritchett L. and Busby, G. (2003) 'The Varieties of Rentier Experience: How Natural Export Structures Affect the Political Economy of Economic Growth', Middlebury College Economics Discussion Paper no. 03-08.

Joireman, S. (2006) 'The Evolution of the Common Law: Legal Development in Kenya and India', Journal of Commonwealth and Comparative Studies 41 (2), pp. 190-210.

Judson, R (1998) 'Economic Growth and Investment in Education: How Allocation Matters', Journal of Economic Growth, 3(4), pp. 337-359

Kmenta, J. (1977) ‘Elements of Econometrics’ New York: Macmillan.

Knack, S. and Keefer, P. (1995), 'Institutions and Economic Performance: Cross-Country Tests Using Alternative Institutional Measures', Economics and Politics, 7, pp. 207-227. Krueger, A. and M. Lindahl (2001) 'Education for Growth: Why and For Whom?' Journal of Economic Literature 39(4), pp. 1101-1136

La Porta, R., Lopez-de-Silanes, F., Pop-Eleches, C. and Shleifer, A. (2004) 'Judicial Checks and Balances', Journal of Political Economy, 112 (2), pp. 445-470. 
La Porta, R., Lopez-de-Silanes, F., Shleifer, A. and Vishny, R. (1998) 'The Quality of Government', NBER Working Paper 6727.

Landes, D. (1997) The Wealth and Poverty of Nations. New York: Norton

Lange, M., Mahoney J. and vom Hau, M. (2006) 'Colonialism and Development: Comparative Analysis of Spanish and British Colonies', American Journal of Sociology 111(5) pp. 1412-1462

Limongi, F. and Przeworski, A. (1993) 'Political Regimes and Economic Growth', Journal of Economic Perspectives, 7 (3), pp. 51-69.

Lindert, P. H. (1999) 'Democracy, Decentralisation, and Mass Schooling Before 1914', Working Paper 104, Agricultural History Centre, University of Davis.

Lipset, S. M. (1959) 'Some Social Requisites for Democracy: Economic Development and Political Legitimacy', American Political Science Review, 53, pp. 69-105.

Lipset, S. M. (1960) 'The Political Man: the Social Basis of Modern Politics', New York: Doubleday.

Lloyd, C.B., Kaufman, C.E. and Hewett, P. (2000) 'The Spread of Primary Schooling in Sub-Saharan Africa: Implications for Fertility Change', Population and Development Review, 26 (3), pp. 483-515.

Lloyd, C.B., Kaufman, C.E. and Hewett, P. (2000) 'The Spread of Primary Schooling in Sub-Saharan Africa: Implications for Fertility Change', Policy Research Division Working Paper, 127.

Lugard, F.D. (1929) 'The Dual Mandate in British Tropical Africa' William Blackwood \& Sons Ltd, London. 
Lugard, Lord, F.D. (1919) 'Methods of Native Administration: Political Officers and Native Rulers', in: R.O. Collins (ed) Problems in The History of Colonial Africa 18601960, (1970), Prentice-Hall, Inc, Englewood Cliffs, N.J, pp. 103-118.

Maddison, A. (1995) 'Monitoring the World Economy 1820-1992', Development Centre Studies, OECD.

Marshall, M.G. and Jaggers, K. (2002) 'Polity IV Project', Center for International Development and Conflict Management, University of Maryland.

Mbay, A.A. (2002) 'An Industry Level Analysis of Manufacturing Productivity in Senegal', Africa Region Working Paper Series 41.

Morgan, W.R. and Armer, J.M. (1988) 'Islamic and Western Educational Accommodation in a West-African Society: A Cohort-Comparison Analysis', American Sociological Review, 53 (4), pp. 634-639.

North, D.C. (1990) 'Institutions, Institutional Change and Economic Performance', Cambridge: Cambridge University Press.

Ntiri, D.W. (1993) ‘Africa’s Educational Dilemma: Roadblocks to Universal Literacy for Social Integration and Change', International review of Education, 39 (5), pp. 357-372.

Nunn, N. (2007), ‘The Long-Term Effects of Africa's Slave Trades' MPRA Paper 4134, University Library of Munich, Germany.

Nunn, N. (2007), 'The Legacy of Exploitation: a Model of Africa's Underdevelopment' Journal of Development Economics, 83 (1), pp. 157-175

Ogunsheye, A. (1965) 'Nigeria', pp. 123-143 in Education and Political Development, (1965) edited by J.S Coleman, Princeton University Press.

Persson, T., Tabellini, G. (2000) 'Political Economics: Explaining Economic Policy', MIT Press. 
Pritchett, L. (2000) 'Where Has All the Education gone?' World Bank Economic Review $15(3)$.

PRS Group, International Country Risk Guide (ICRG); www.prsgroup.com

Rajan, R.G., Zingales, L. (2006) 'The Persistence of Underdevelopment: Institutions, Human Capital, or Constituencies?', NBER Working Paper 12093.

Rehme, G (2007) 'Education, Economic Growth and Measured Income Inequality', Economica 74 (295), pp. 493-514

Rodrik, D. A. Subramanian, and F. Trebbi (2002), 'Institutions Rule: The Primacy of Institutions over Geography and Integration in Economic Development', NBER Working Paper 9305.

Rodrik, D. (1999) 'Where Did All the Growth Go? External Shocks, Social Conflict, and Growth Collapses', Journal of Economic Growth, 4 (4), pp. 385-412.

Rodrik, D. (2002), 'Institutions, Integration, and Geography: In Search of the Deep Determinants of Economic Growth', in: Rodrik (ed), In Search of Prosperity: Analytical Country Studies on Growth, Princeton University Press, Princeton, NJ, 2003

Rodrik, D., Subramanian, A. and Trebbi, F. (2002) 'Institutions Rule: The Primacy of Institutions Over Geography and Integration in Economic Development', NBER Working Paper 9305.

Sachs, J.D. (2001) 'Tropical Underdevelopment', NBER Working Paper 8119.

Sachs, J.D. (2003) 'Institutions Don't Rule: Direct Effects of Geography on Per Capita Income', NBER Working Paper 9490.

Sachs, J.D. and Warner, A.M. (1997) 'Sources of Slow Growth in African Economies', Journal of African Economies, 6 (3), pp. 335-376. 
Schultz, T.P. (1999) 'Health and Schooling Investments in Africa', Journal of Economic Perspectives, 13 (3), pp. 67-88.

Schultz, T.W. (1961) 'Investment in Human Capital', The American Economic Review, $51(1)$, pp. 1-17.

Sokoloff, K.L. and Engerman, S.L. (2002), 'Factor Endowments, Inequality, and Paths of Development Among New World Economies', NBER Working Paper 9259

Sutton, F.X. (1965) 'Education and the Making of Modern Nations', in: by J.S Coleman (ed) Education and Political Development, Princeton University Press pp. 51-74.

Stateuniversity (2008) hhtp://education.stateuniversity.com/pages/1585/Ugandaeducational-stsem. Accessed July 8, 2008.

Tanzi and H. Davoodi (1998) 'Roads to Nowhere: How Corruption in Public Investment Hurts Growth'. Washington, D.C.: International Monetary Fund.

Tilly, C. (1998) Durable Inequality, University of California Press, Berkeley.

Timmer, C.P. (2002) 'Agriculture and Economic Developemt' in: B. Gardner and G. Rausser (ed) Handbook of Agricultural Economics, (2002) volume 2.

Topel, R (1999) Labor Markets and Economic Growth, In: O. Ashenfelter and D. Card, (eds.) Handbook of Labor Economics, Amsterdam: North Holland.

Vinod, H and Kaushik, S (2007) 'Human Capital And Economic Growth: Evidence From Developing Countries', American Economist 51 (1), pp. 29-39

Weingast, B. (1997) 'The political foundations of democracy and the rule of law' American Political Science Review, 91 (2), pp. 245-263.

Wesseling, H.L. (1991) 'Verdeel en Heers: de Deling van Afrika 1880-1914 ‘

Amsterdam: Bakker. 


\begin{abstract}
White, B.W. (1996) 'Talk about School: education and the colonial project in French and British Africa (1860-1960)', Comparative Education, 32 (1), pp. 9-25.

Wiseman, J.A. (1996) 'The New Struggle for Democracy in Africa', Aldershot UK.

Working Paper No. 4349.

World Bank, 'World Development Indicators 2005', Washington DC: The World Bank. World Bank, 'World Development Indicators 2006', Washington DC: The World Bank.
\end{abstract}


${ }^{1}$ Obviously, this is not to say that education is therefore an unmixed blessing; the formation of human capital enabling economic growth may still co-exists with for example cultural repression perpetuated through educational systems.

2 Total number of pupils divided by total population. See appendix B for sources.

3 Average years of primary schooling in the total population over age 15, taken from the Barro and Lee data set (Barro and Lee 2001).

4 See Appendix B for sources.

${ }^{5}$ We present an overview of key statistics in the data Appendix A.

${ }^{6}$ As proxies for colonial-era institutions Acemoglu et al. (2001) used a democracy index at the first year of independence, varying between the 1950's and 1975, an index measure for constraint on the executive at first year of independence, where more constraints reflect better institutions.

${ }^{7}$ An important reason underlying this result may also be that the stability over time of institutions assumed in Acemoglu et al. (2001) should be questioned in the African context. African colonial-era institutions do not correlate well with current institutions (which cause current GDP). Twenty-four of the 44 African countries included in the Polity IV data experienced shortly after independence an (often sharp) decline in the democracy index used here and in Acemoglu et al. (2001). Of the 14 countries with a low initial measure for 'constraint on the executive', 6 countries showed an appreciable improvement subsequently. This volatility links in with a cross-country analyses of institutional indices by Glaeser et al. (2004) who note that these index measures tend to reflect short-term changes (for example election results) rather than the stabler, underlying institutions.

${ }^{8}$ We chose 1995 to allow comparison to Acemoglu et al (2001).

${ }^{9}$ Note that including COASTPOP and LANDLOCKED does not amount to the same thing since they are quite different variables. There are countries with coastlines (LANDLOCK=0) such as Kenya, but with coastal populations of only 6 percent. Compare also Mozambique (40\%), Sudan (2\%) and Tanzania (16\%) ( Gallup et al. 1998:31)

${ }^{10}$ TROPICS has little variation within Africa, with many values equal or close to $100 \%$. Excluding it improves the significance of findings, without qualitatively changing them.

${ }^{11}$ We chose 1995 to allow comparison to Acemoglu et al (2001).

${ }^{12}$ We combine an instrumental variable approach with generalized least squares, which accounts for the correlation structure in the disturbances across equations. This procedure, also known as 'three stage least squares', results in consistent estimates that are more efficient than 2sls without using the information contained in cross-equation correlations of 
disturbances. We estimated our equations also without GLS (i.e. 'simple' 2sls), which produces qualitatively identical, but less significant estimates, as expected. See Kmenta (1977) and Greene (2003) for more detail.

${ }^{13}$ An instrumented model without control variables, regressing LOG GDP pc in 1995 only on PUPILS (instrumented with SETTMORT) plus a constant, yields a similar coefficient estimate (0.24.941) and significance levels (s.e. is 12.897) for PUPILs as model (1), but has a negative $\mathrm{R} 2$ indicating under-specification.

${ }^{14}$ Instrumenting colonial human capital with other (legal-origin or geographical) exogenous variables did not yield statistically significant explanations of 1995 GDP. Although colonial education does correlate with several of the exogenous variables considered here, only settler mortality is a suitable instrument for human capital variables in an equation explaining 1995 GDP. Results from these additional analyses are available on request from the authors.

${ }^{15}$ Our newly compiled data set allowed us to also consider health, another dimension of human capital. In IV and OLS regressions of HOSPITALS, a measure for colonial healthcare (the number of hospitals per 1000 population health), again using settler mortality as the instrument, on 1995 GDpc, HOSPITAL yields a valid instrumental-variable explanation of present GDP levels. But model performance is very weak, with a negative R2 indicating that a constant-only model would predict better. Also, the relation between colonial health and present pc GDP relation was not robust to introducing controls.

${ }^{16}$ Interestingly, Lange et al.(2006:1412) find that 'British colonization had comparatively positive effects' on economic development, that is compared to Spanish colonization.

${ }^{17}$ Average years of primary schooling in the total population over age 15, taken from the Barro and Lee data set (Barro and Lee 2001). Using World Development Indicators as the source yields similar results.

${ }^{18}$ Results from the 2SLS analysis are available on request from the authors.

${ }^{19}$ We are grateful to an anonymous referee for suggesting this. 


\section{Appendix A: Geographical and Institutional Data}

We thank Acemoglu for kindly providing the data on which the Acemoglu et al. (2001)

results are based; and Gallup, Sachs and Mellinger for making their data on which the Gallup et al. (1998) results are based available on the Internet.

\section{Data description}

\begin{tabular}{|c|c|c|}
\hline Variable & Year & Source \\
\hline Settler Mortality & $1800-1850$ & Acemoglu et al, 2001 \\
\hline \multicolumn{3}{|c|}{$\begin{array}{l}\text { Settler mortality is potential settler mortality measured in terms of deaths per annum per } 1000 \text { 'mean } \\
\text { strength' (raw mortality numbers are adjusted to what they would be if a force of } 1000 \text { living people } \\
\text { were kept in place for a whole year). }\end{array}$} \\
\hline Democracy at first year of independence before 1975 & Various years & Polity IV \\
\hline \multicolumn{3}{|c|}{$\begin{array}{l}\text { Democracy indicator based on the competitiveness of political participation, openness and } \\
\text { competitiveness of executive recruitment and constraints on the executive. Scale between } 0 \text { and } 10 \text {, } \\
\text { where higher scores indicate more democracy. Year of observation is the first year of independence } \\
\text { as long as that is before 1975, otherwise the country gets a score of } 1 \text { (in line with Acemoglu et al } \\
2001 \text { ). }\end{array}$} \\
\hline Constraint on the executive before 1975 & Various years & Polity IV \\
\hline \multicolumn{3}{|c|}{$\begin{array}{l}\text { Measure of the extent of institutionalised constraints on the decision making powers of chief } \\
\text { executives, whether individuals or collectivises. Scale between } 0 \text { and } 7, \text { where higher scores indicate } \\
\text { more constraints. Year of observation is the first year of independence as long as that is before 1975, } \\
\text { otherwise the country gets a score of } 1 \text { (in line with Acemoglu et al 2001). }\end{array}$} \\
\hline PopCoast & 1994 & Gallup et al 1998 \\
\hline \multicolumn{3}{|c|}{ Proportion of the population living within $100 \mathrm{~km}$ of the coastline. } \\
\hline Landlocked dummy & & Gallup et al 1998 \\
\hline \multicolumn{3}{|c|}{ A binary dummy, with a value one indicating landlockedness } \\
\hline Malaria index & 1966,1994 & Gallup et al 1998 \\
\hline \multicolumn{3}{|c|}{$\begin{array}{l}\text { Index of Malaria prevalence based on a global map of extent of malaria in } 1966 \text { (WHO 1967), and the } \\
\text { fraction of falciparum malaria. 'The index is the product of the fraction of land area subject to malaria } \\
\text { times the fraction of falciparum malaria cases'. (Gallup et al 1998) }\end{array}$} \\
\hline Life expectancy 1965 & 1965 & Gallup et al 1998 \\
\hline
\end{tabular}


Data Gallup et al took form the United Nations

\begin{tabular}{|l|r|l|} 
& & \\
\hline Tropic & 1996 & Gallup et al 1998 \\
\hline The proportion of a country's land area within the geographical tropics
\end{tabular}

The proportion of a country's land area within the geographical tropics

\begin{tabular}{|l|l|l|}
\hline LEGALORIGIN & & \\
\hline $\begin{array}{l}\text { Binary dummy, where value one indicates a former } \\
\text { British colony. }\end{array}$ & & \\
& Authors \\
\hline Hydrocarbons & 1993 & Gallup et al 1998 \\
\hline
\end{tabular}

Hydrocarbon deposits are total BTU's per person of proven crude oil and natural gas reserves in 1993, which Gallup et al collected from World Resource Database (1996-1997)

\section{Appendix B: Collected Colonial Data}

Our newly constructed date set is comprised of data on former British and French colonies in Africa. Based on colonial yearbooks of the years 1945-1955 (detailed sources are below), we calculated variables that could serve as proxies for the general institutional environment between 1945 and 1950. The data set consists of four modules: a) population density and European presence (calculated as density per squared kilometre and as the proportion of Europeans to total population) in countries is collected. b) human capital: school pupils as a proportion to total population.

\section{Sources}

French West Africa (Benin, Burkina Faso, Cote d'Ivoire, Guinea, Mali, Mauritania, Niger, Senegal)

French Equatorial Africa (Central African Republic, Chad, Congo Republic, Gabon) Madagascar Botswana
Annuaire Statistique de L'Afrique Occidentale Francaise, 1949 Volume 4, and 1950 à 1955 Volume 5

Annuaire Statistique de L'Afrique Equatoriale Française, 1936-1950 Volume 1, 1951 à 1955 Volume 2 Annuaire Statistique de Madagascar, 1938 - 1951, Vol. 1 Official Year Book of the Union [of South Africa] and of Basutoland [Lesotho], Bechunanaland Protectorate [Botswana] and Swaziland, 1950 no 26.

Ghana Economic and Statistical Bulletin of the Gold Coast, April 


\section{Variable description and availability}

Tanzania

Uganda

Nigeria

Digest of Statistics, November 1953, No. 4

\begin{tabular}{|c|c|}
\hline Kenya & Statistical Abstract, 1955 \\
\hline Lesotho & $\begin{array}{l}\text { Official Year Book of the Union [of South Africa] and of } \\
\text { Basutoland [Lesotho], Bechunanaland Protectorate } \\
\text { [Botswana] and Swaziland, } 1950 \text { no } 26 .\end{array}$ \\
\hline \multirow[t]{2}{*}{ Malawi } & $\begin{array}{l}\text { Federation of Rhodesia and Nyasaland: Census of } \\
\text { Population } 1956\end{array}$ \\
\hline & Monthly Digest of Statistics, April 1955, Vol 2, No. 1 \\
\hline \multirow[t]{3}{*}{ Mauritius } & $\begin{array}{l}\text { Final report on the Census Enumeration made in the } \\
\text { Colony of Mauritius and its Dependencies on 11th June, } \\
1944\end{array}$ \\
\hline & $\begin{array}{l}\text { Blue Book of the Colony of Mauritius and its } \\
\text { Dependencies, } 1946 / 1947\end{array}$ \\
\hline & Yearbook of Statistics, 1959 No. 14. \\
\hline \multirow[t]{2}{*}{ Nigeria } & Blue Book for the year ending 31st December, 1938. \\
\hline & $\begin{array}{l}\text { Digest of Statistics, Vol. 2, October 1952, No. } 1 \text { and } 4 . \\
\text { Digest of Statistics } 1956\end{array}$ \\
\hline \multirow[t]{2}{*}{ Sudan } & $\begin{array}{l}\text { Foreign Trade Report (with some internal statistics), } \\
1949\end{array}$ \\
\hline & $\begin{array}{l}\text { First population census of Sudan 1955/56, Final Report, } \\
\text { vol. } 1\end{array}$ \\
\hline Swaziland & $\begin{array}{l}\text { Official Year Book of the Union [of South Africa] and of } \\
\text { Basutoland [Lesotho], Bechunanaland Protectorate } \\
\text { [Botswana] and Swaziland, } 1950 \text { no } 26 .\end{array}$ \\
\hline Tanzania & Statistical Abstract, 1938-1952 (Tanganyika) \\
\hline Uganda & Statistical Abstract, 1957 \\
\hline \multirow[t]{3}{*}{ Zambia } & $\begin{array}{l}\text { Federation of Rhodesia and Nyasaland: Census of } \\
\text { Population } 1956\end{array}$ \\
\hline & Monthly Digest of Statistics, April 1955, Vol. 2, No. 1 \\
\hline & $\begin{array}{l}\text { Economic and Statistical Bulletin (Northern Rhodesia), } \\
\text { February 1953, Vol. 5, No. } 11\end{array}$ \\
\hline \multirow[t]{2}{*}{ Zimbabwe } & $\begin{array}{l}\text { Federation of Rhodesia and Nyasaland: Census of } \\
\text { Population } 1956 .\end{array}$ \\
\hline & $\begin{array}{l}\text { Monthly Digest of Statistics, April 1955, Vol 2, No. } 1 \\
\text { Official Year Book of Southern Rhodesia, 1952, No. } 4\end{array}$ \\
\hline Additional data on Education & $\begin{array}{l}\text { Mitchell, B.R. (2003) } 4^{\text {th }} \text { edition } \\
\text { The Statesman's Year-Book }(1946,1948,1955) .\end{array}$ \\
\hline
\end{tabular}

\begin{tabular}{llcl} 
Variable & Description & Year & \multicolumn{1}{c}{ Source } \\
\hline Population & Total population per squared & $1948-55$ & French West Africa (Benin, \\
Density & kilometre & & Burkina Faso, Cote d'Ivoire,
\end{tabular}




\begin{tabular}{|c|c|}
\hline $1950-55$ & $\begin{array}{l}\text { French Equatorial Africa (Central } \\
\text { African Republic, Chad, Congo } \\
\text { Republic, Gabon) }\end{array}$ \\
\hline $1946-51$ & Madagascar \\
\hline $1948-53$ & Ghana \\
\hline $1947-51$ & Kenya \\
\hline $1946-51$ & Malawi \\
\hline $1946-47$ & Mauritius \\
\hline $1938-50$ & Nigeria \\
\hline $1936,46,50$ & Botswana \\
\hline $1936,46,50$ & Lesotho \\
\hline 1949-55 & Sudan \\
\hline $1936,46,50$ & Swaziland \\
\hline 1947-52 & Tanzania \\
\hline 1947-51 & Uganda \\
\hline $1946-51$ & Zambia \\
\hline $1946-51$ & Zimbabwe \\
\hline
\end{tabular}

\section{European} density
Total European population per squared kilometre
1948-55 French West Africa (Benin, Burkina Faso, Cote d'Ivoire, Guinea, Mali, Mauritania, Niger, Senegal)

1950-55 French Equatorial Africa (Central African Republic, Chad, Congo Republic, Gabon)

1946-51 Madagascar

1948-53 Ghana

1947-51 Kenya

1946-51 Malawi

1946-47 Mauritius

1938-50 Nigeria

1936,46,50 Botswana

$1936,46,50$ Lesotho

1949-55 Sudan

$1936,46,50$ Swaziland

1947-52 Tanzania

1947-51 Uganda

1946-51 Zambia

1946-51 Zimbabwe

European $\quad$ Total European population as
percentage of total population

French West Africa (Benin, Burkina Faso, Cote d'Ivoire, Guinea, Mali, Mauritania, Niger, Senegal)

1950-55 French Equatorial Africa (Central African Republic, Chad, Congo Republic, Gabon)

1946-51 Madagascar

1948-53 Ghana

1947-51 Kenya

1946-51 Malawi

1946-47 Mauritius

URL: http://mc.manuscriptcentral.com/fjds 
